\title{
Pawet Oleksy
}

Katedra Rynków Finansowych

Uniwersytet Ekonomiczny w Krakowie

\section{Erozyjny wpływ kosztów funduszy inwestycyjnych na wartość kapitału inwestorów w Polsce na tle wybranych krajów europejskich}

\section{Streszczenie}

Spośród czynników, które w całym okresie funkcjonowania funduszu inwestycyjnego, niezależnie od jego formy prawnej, specjalizacji czy zakresu działania, wywołują efekt erozji wartości bogactwa inwestorów istotną rolę odgrywa poziom kosztów, jaki inwestorzy ponoszą bezpośrednio lub pośrednio $\mathrm{w}$ związku $\mathrm{z}$ tą inwestycją. $\mathrm{Z}$ przeprowadzonych z wykorzystaniem wskaźnika bogactwa końcowego Sharpe’a badań wynika, że wywołana wysokością obciążeń kosztowych skala erozji bogactwa końcowego związanego $\mathrm{z}$ inwestowaniem $\mathrm{w}$ fundusze w przypadku Polski znacznie przewyższa - ceteris paribus - porównywalne inwestycje realizowane w objętych badaniami krajach europejskich. Dysproporcja w wartości końcowej kapitału jest pochodną wysokości naliczanych opłat manipulacyjnych oraz kosztów operacyjnych i narasta w miarę wydłużania horyzontu inwestycyjnego. Przykładowo dla czterdziestoletniego okresu inwestycji, wywołana wyłącznie dysproporcją w kosztach wysokość końcowych wyników z inwestycji osiąganych przez inwestorów z Polski, różni się średnio od wyników europejskich o $35 \%$ w przypadku funduszy gotówkowych i pieniężnych, o 42\% - w przypadku funduszy dłużnych, o 197\% - w przypadku funduszy akcyjnych oraz o 234\% - w przypadku funduszy mieszanych.

Fakt ten świadczy zarówno o niedojrzałości polskiego rynku funduszy inwestycyjnych, jak i o ciągle jeszcze niskiej świadomości ekonomicznej rodzimych inwestorów, co przy braku wystarczającego zaangażowania instytucji publicznych odpowiedzialnych za nadzór i funkcjonowanie tego segmentu rynku finansowego w proces tworzenia taniego, 
efektywnego i bezpiecznego mechanizmu alokacji oszczędności społeczeństwa przyczynia się do znacznie głębszej erozji ich bogactwa aniżeli w krajach rozwiniętych.

Słowa kluczowe: fundusze inwestycyjne, koszty działalności funduszy, wskaźnik bogactwa końcowego, erozja wartości kapitału.

\section{Wprowadzenie}

Jedną z możliwości alokacji kapitału na rynkach finansowych, zapewniającą inwestorom indywidualnym oraz instytucjonalnym dostęp do profesjonalnych usług w zakresie zarządzania portfelem inwestycyjnym oraz jego szeroką dywersyfikację, jest inwestowanie w instrumenty finansowe oferowane przez fundusze inwestycyjne ( $\mathrm{tj}$. jednostki uczestnictwa, certyfikaty inwestycyjne, tytuły uczestnictwa w funduszach zagranicznych). Na końcową wartość kapitału (bogactwa) ${ }^{1}$ inwestorów (terminal wealth value) z tego typu inwestycji wpływ ma wiele czynników, zarówno o charakterze endogenicznym (np. strategia inwestycyjna funduszu, wysokość opłat, wykształcenie i doświadczenie zarządzających), jak i egzogenicznym (np. bieżąca sytuacja na rynku giełdowym, polityka banku centralnego w zakresie kształtowania stóp procentowych, obciążenia podatkowe związane z inwestycją, inflacja, czy zmiany kursu walutowego w przypadku instrumentów finansowych denominowanych w walutach obcych). Spośród czynników, które w całym okresie funkcjonowania funduszu, niezależnie od jego formy prawnej, specjalizacji czy zakresu działania, wywołują efekt erozji wartości bogactwa inwestorów istotną rolę odgrywa poziom kosztów, jaki inwestorzy ponoszą bezpośrednio lub pośrednio w związku z tą inwestycją.

Ogólnie ujmując, koszty obciążające fundusz inwestycyjny obejmują inter alia koszty zarządzania portfelem inwestycyjnym, koszty administracyjne, różnorodne opłaty (rejestrowe, dystrybucyjne, za zezwolenia), koszty usług świadczonych przez podmioty zewnętrzne (np. prawne, wydawnicze, w zakresie rachunkowości i audytu), czy też koszty stricte finansowe, tj. odsetki od otrzymanych kredytów i pożyczek oraz ujemne różnice kursowe ${ }^{2}$. Ich wielkość

1 W dalszej części artykułu określenia „bogactwo” i „kapitał” traktowane są jako synonimy i odnoszą się stricte do wartości kapitału zgromadzonego przez inwestora w funduszu inwestycyjnym.

2 Szczegółowy sposób oraz zasady naliczania i rozliczania kosztów obciążających fundusz inwestycyjny zarejestrowany w Polsce uregulowane są w przepisach ustawy z 29 września 1994 r. o rachunkowości (Dz.U. 1994, nr 121 poz. 591, z późn. zm.) oraz rozporządzeniu Ministra Finansów z 27 grudnia 2007 r. w sprawie szczególnych zasad rachunkowości funduszy inwestycyjnych (Dz.U. 2007, nr 249 poz. 1859). Dodatkowo w statucie danego funduszu określone muszą być rodzaje, maksymalna wysokość, sposób kalkulacji i naliczania kosztów obciążających fundusz inwestycyjny, w tym w szczególności wynagrodzenie TFI, oraz terminy, w których najwcześniej może nastąpić 
oraz struktura uzależniona jest nie tylko od wartości i rodzaju zgromadzonych w funduszu aktywów, ale zdeterminowana jest również przez inne czynniki, np. dojrzałość lokalnego rynku finansowego, typ funduszu, okres jego działalności, obrana strategia inwestycyjna, przedmiot inwestycji czy zakres oferowanych usług. Poziom niektórych kosztów wynika wprost z regulacji zewnętrznych (np. opłaty sądowe i notarialne, opłaty i prowizje na rzecz instytucji depozytowych, rozliczeniowych oraz prowadzących repozytoria), w zdecydowanej jednak części jest on następstwem przyjętych w danym funduszu rozwiązań i parametrów (np. wynagrodzenie za zarządzanie). Są one pokrywane ze środków pieniężnych będących w dyspozycji funduszu.

Równie istotną, chociaż odrębną, grupę kosztów pomniejszających bogactwo inwestorów stanowią wszelkiego rodzaju opłaty i prowizje manipulacyjne (load fees), pobierane przez niektóre fundusze w momencie wejścia lub wyjścia inwestorów z inwestycji. Obniżając wartość wpłacanego przez inwestora na początku lub otrzymywanego przez niego na końcu inwestycji kapitału, redukują istotnie jej efektywność, a częstokroć przesądzają o jej nieopłacalności.

Konieczność ponoszenia przez inwestujących w fundusze różnorodnych kosztów manipulacyjnych i operacyjnych nie budzi wątpliwości. Dyskusyjna może być jedynie ich skala oraz struktura, biorąc zwłaszcza pod uwagę fakt istotnej asymetrii ryzyka osiągnięcia wartości dodanej (przyrostu bogactwa) przez właścicieli funduszy oraz ich uczestników.

Problem ten jest szczególnie istotny w okresie dynamicznych przeobrażeń na rynkach finansowych i alternatywnych, wzrastającej zmienności cen i różnorodności aktywów inwestycyjnych, a tym samym ich coraz większego oddziaływania na długookresową wartość bogactwa inwestorów. $Z$ tego też powodu poszukiwanie optymalnego rozwiązania w zakresie kształtowania poziomu kosztów funduszy inwestycyjnych jest zadaniem niezmiernie ważnym i aktualnym. W pewnym stopniu wymaga również zaangażowania instytucji publicznych odpowiedzialnych za nadzór i funkcjonowanie danego rynku lokalnego, w celu stworzenia warunków do rozwoju taniego, efektywnego i bezpiecznego mechanizmu alokacji oszczędności społeczeństwa.

\section{Przegląd dotychczasowych badań}

Problematyka wpływu kosztów funduszu na wartość zdeponowanego przez inwestorów kapitału jest od kilku dekad przedmiotem intensywnych badań naukowych. Ze względu na znaczne dysproporcje w rozwoju lokalnych rynków 
funduszy inwestycyjnych na świecie badania te odnoszą się głównie do analizy zależności pomiędzy kosztami a wynikami funduszy w krajach o rozwiniętych rynkach kapitałowych, tj. USA, Kanada czy kraje Europy Zachodniej.

Wyniki przeprowadzonych dotychczas badań uwidaczniają generalną prawidłowość, że fundusze inwestycyjne osiągają przeciętnie gorsze wyniki od rynkowych indeksów odniesienia, biorąc pod uwagę osiągane stopy zwrotu netto, tj. skorygowane o ryzyko i koszty danego funduszu (risk-adjusted net returns) [Bello i Frank 2010, Wermers 2000]. Ponadto fundusze charakteryzujące się niskimi kosztami funkcjonowania generują zazwyczaj wyższe stopy zwrotu aniżeli fundusze obciążone wysokimi kosztami [Hooks 1996]. Realizowanie aktywnej strategii zarządzania portfelem inwestycyjnym determinuje bowiem konieczność ponoszenia wyższych kosztów, co często nie ma jednak pozytywnego przełożenia na osiągane stopy zwrotu netto [Grinblatt i Titman 1989]. Teza o ujemnej korelacji pomiędzy poziomem kosztów a efektywnością funduszu znajduje z kolei potwierdzenie zarówno w badaniach rynku funduszy inwestycyjnych w krajach europejskich, takich jak Francja, Holandia, Niemcy, Wielka Brytania [Otten i Bams 2002], jak i dotyczących rynku amerykańskiego [Carhart 1997].

W Polsce dominują ogólne badania i analizy efektywności funduszy inwestycyjnych z wykorzystaniem podejścia technicznego, koncentrujące się na ocenie wyników działalności funduszy odzwierciedlonych w wysokościach realizowanych stóp zwrotu, poziomach ponoszonego ryzyka, a przez to w wartościach tradycyjnych mierników efektywności, m.in. Sharpe'a, Treynora, Jensena (m.in. [Perez 2012, Zamojska 2012, Dawidowicz 2011]). W ograniczonym zakresie prowadzona jest natomiast analiza wpływu cech fundamentalnych, w szczególności poziomu kosztów, na efektywność poszczególnych funduszy (m.in. [Oleksy 2013, Księżak 2013a, Palica 2007, Krawiec 2003]).

Warto wspomnieć także o etycznym wymiarze problemu obciążania inwestorów w funduszach inwestycyjnych zróżnicowanymi kosztami i opłatami. Jak ukazują w swoich badaniach T. Houge i J. Wellman [2007], wyrafinowana segmentacja klientów umożliwia funduszom inwestycyjnym czerpanie korzyści z obciążania mniej świadomych inwestorów (less-knowledgeable customers) wyższymi kosztami i opłatami, co rodzi uzasadnione wątpliwości natury moralnej. Weryfikując dane z amerykańskich funduszy akcyjnych i obligacyjnych działających w latach 1970-2004, wykazali oni, że inwestując w te same fundusze inwestorzy mniej świadomi ponoszą systematycznie wyższe opłaty z tytułu zarządzania aktywami aniżeli tzw. klienci bardziej świadomi (more-knowledgeable customers). Rozróżniając oba typy inwestorów, przyjęli, że bardziej świadomi (kompetentni) inwestorzy są skłonni do zakupu tytułów uczestnictwa w funduszach bezpośrednio od ich dystrybutorów, unikając wszel- 
kich prowizji od sprzedaży i opłat manipulacyjnych, natomiast inwestorzy mniej świadomi (mniej pewni) poszukują wsparcia u maklerów lub doradców finansowych, pobierających za swe usługi dodatkowe wynagrodzenie.

$\mathrm{Na}$ konieczność nowego spojrzenia na problematykę wpływu kosztów funduszu na finansowy dobrobyt inwestorów wskazuje $\mathrm{z}$ kolei jeden z prekursorów badań nad wyceną aktywów finansowych i oceną efektywności inwestycji na rynku kapitałowym - W.F. Sharpe [2013]. Prezentując nową metodykę oceny względnego poziomu bogactwa inwestorów alokujących swe środki długookresowo w fundusze o odmiennych wskaźnikach kosztów, wykazuje on, że pod prawdopodobnymi warunkami osoba oszczędzająca na swoją emeryturę, która dokonuje wyboru funduszu niskokosztowego (low-cost investment), może mieć w całym okresie emerytalnym standard życia o ponad $20 \%$ wyższy aniżeli inwestor, dokonujący porównywalnej inwestycji w fundusz wysokokosztowy (high-cost investment). Dochodzi do wniosku, podobnie jak C.D. Ellis [2012], że opłaty pobierane przez fundusze aktywnie zarządzane są bardzo wysokie w stosunku do stanowiących ich alternatywę funduszy pasywnych.

\section{Cel pracy i hipoteza badawcza}

Celem niniejszego artykułu jest weryfikacja skali długookresowego efektu erozji wartości kapitału alokowanego przez inwestorów indywidualnych i instytucjonalnych w funduszach inwestycyjnych działających w Polsce na tle wybranych krajów europejskich, wywołanego - ceteris paribus - przez koszty obciążające inwestycje w fundusze, odzwierciedlone w wysokościach wskaźników Total Expense Ratio (TER). U podstaw prowadzonej analizy leży hipoteza badawcza stwierdzająca, że inwestycje w fundusze działające na rynku polskim obarczone są niewspółmiernie wysokimi kosztami w porównaniu z inwestycjami o podobnym charakterze realizowanymi w krajach Europy Zachodniej, co w długim okresie przyczynia się do relatywnie wysokiego ubytku bogactwa końcowego rodzimych inwestorów. Przyczyną takiego stanu rzeczy jest inter alia niedojrzałość lokalnego rynku funduszy inwestycyjnych, niska świadomość ekonomiczna inwestorów, a także niedostateczne zaangażowanie instytucji nadzorujących rynek w kreowanie systemowych rozwiązań zapobiegających nadmiernej erozji wartości oszczędności inwestorów (np. w zakresie limitów stawek poszczególnych opłat czy zasad finansowej odpowiedzialności właścicieli funduszy za osiągane przez nie wyniki ekonomiczne). 


\section{Metodyka badań i dane}

Badanie przeprowadzono z wykorzystaniem zaproponowanego przez W. Sharpe’a wskaźnika kapitału (bogactwa) końcowego - Terminal Wealth Ratio (TWR) [Sharpe 2013]. W ogólnym ujęciu określa on stopień zróżnicowania końcowych wyników z inwestycji w fundusze w przyjętym horyzoncie czasowym wywołany występowaniem różnic $\mathrm{w}$ wysokości ponoszonych przez inwestorów kosztów inwestycji oraz osiąganych przez nich stóp zwrotu. Umożliwia porównywanie wyników oraz skali obciążeń zarówno w ujęciu historycznym, jak i w perspektywie ex ante przy wykorzystaniu różnorodnych metod symulacyjnych. W niniejszym artykule algorytm jego obliczania został zaprezentowany jedynie w odniesieniu do jednego tylko przypadku, tj. inwestycji polegającej na lokowaniu w tytuły uczestnictwa funduszu kapitału początkowego $K_{0}$ na $n$ okresów.

Przyjmując, że $x_{t}$ jest miarą obciążenia kosztami inwestycji w dany fundusz $\mathrm{w} t$-tym okresie (np. w $t$-tym roku), zaś $r_{t}$ - zrealizowaną (lub oczekiwaną) stopą zwrotu brutto w tym okresie, to wartość końcowa $K_{n}$ kapitału początkowego $K_{0}$ zainwestowanego na początku inwestycji na $n$ okresów jest równa - w przypadku kapitalizacji złożonej z dołu - iloczynowi tego kapitału oraz stóp zwrotu netto w poszczególnych okresach:

$$
K_{n}=K_{0} \cdot\left[\left(1-x_{1}\right) \cdot\left(1+r_{1}\right) \cdot \ldots \cdot\left(1-x_{n}\right) \cdot\left(1+r_{n}\right)\right]=K_{0} \cdot \prod_{t=1}^{n}\left[\left(1-x_{t}\right) \cdot\left(1+r_{t}\right)\right]
$$

lub po przekształceniu:

$$
\begin{aligned}
K_{n} & =K_{0} \cdot\left[\left(1-x_{1}\right) \cdot \ldots \cdot\left(1-x_{n}\right)\right] \cdot\left[\left(1+r_{1}\right) \cdot \ldots \cdot\left(1+r_{n}\right)\right]= \\
& =K_{0} \cdot \prod_{t=1}^{n}\left(1-x_{t}\right) \cdot \prod_{t=1}^{n}\left(1+r_{t}\right) .
\end{aligned}
$$

W ramach analizy porównawczej inwestycji w fundusze dokonuje się obliczenia końcowej wartości kapitału dla każdego z nich, a w następnej kolejności określenia współczynników bogactwa końcowego $(T W R)$, dzieląc pomiędzy sobą otrzymane wartości kapitału $K_{n}$ dla poszczególnych funduszy, tj.:

$$
T W R_{i j}=\frac{K_{n i}}{K_{n j}},
$$

gdzie:

$T W R_{i j}$ - wskaźnik bogactwa końcowego inwestycji w $i$-ty fundusz w porównaniu $\mathrm{z}$ inwestycją $\mathrm{w} j$-ty fundusz,

$K_{n i}$ - końcowa wartość inwestycji w $i$-tym funduszu,

$K_{n j}$ - końcowa wartość inwestycji w $j$-tym funduszu $(i, j=1,2, \ldots, N)$. 
W szczególnym przypadku, tj. przy założeniu, że kwoty inwestowanego kapitału początkowego $K_{0}$ i okres inwestycyjny są równe oraz fundusze osiągają w każdym z okresów jednakowe stopy zwrotów $r_{t}$, zaś różnią się jedynie wartością wskaźników kosztów, które dodatkowo są stałe przez cały okres inwestowania w dany fundusz i wynoszą $x_{i}$ dla inwestycji w $i$-ty fundusz oraz $x_{j}$ dla inwestycji $\mathrm{w} j$-ty fundusz, to wartość wskaźnika bogactwa końcowego jest równa wartości złożonego wskaźnika retencji (compounded retention ratio) i wynosi:

$$
T W R_{i j}=\left[\frac{1-x_{i}}{1-x_{j}}\right]^{n} .
$$

Wartość wskaźników kosztów jest kalkulowana na bazie danych z okresowych sprawozdań finansowych funduszy oraz publikowana w specjalistycznych serwisach finansowych i portalach inwestycyjnych. Określane w USA jako $E R$ (expense ratios), w krajach europejskich jako TER (total expense ratios), obejmują one zwykle szerszą grupę kosztów obciążających fundusz aniżeli wyłącznie wynagrodzenie za zarządzanie [Khorana, Servaes i Tufano 2008]. W praktyce są one kalkulowane jako stosunek kosztów operacyjnych netto funduszu po odjęciu kosztów odsetkowych oraz ujemnego salda różnic kursowych do średniej wartości aktywów netto w danym okresie [Księżak 2013b].

Na potrzeby prowadzonych obliczeń przyjęto wartości mediany ważonych aktywami wskaźników kosztów (TER) dla wybranych krajów, opublikowane w raporcie rocznym Global Fund Investor Experience Report [2013]. Dane te odnoszą się do funduszy dłużnych (fixed-income), akcyjnych (equity), mieszanych (allocation) oraz gotówkowych i pieniężnych (money market), oferujących tytuły uczestnictwa dla inwestorów z tego samego rynku lokalnego (locally domiciled). Średnie wartości wskaźników TER dla głównych grup funduszy z rynku polskiego według stanu na 30 czerwca 2013 r. uzyskano bezpośrednio z serwisu Analizy.pl. Uwzględniają one wyłącznie fundusze o dłuższym niż 1 rok okresie działalności, zakwalifikowane pierwotnie do następujących grup funduszy: dłużne uniwersalne, akcji polskich uniwersalne, mieszane zrównoważone, gotówkowe i pieniężne.

Dane na temat kształtowania się średnich poziomów wskaźników TER w wybranych typach funduszy inwestycyjnych (dłużnych, akcyjnych, mieszanych, gotówkowych i pieniężnych) w Polsce oraz 11 wybranych krajach europejskich, jak i informacje na temat wielkości poszczególnych rynków lokalnych, zaprezentowano w tabeli 1.

Dodatkowo w celu zobrazowania zróżnicowania poszczególnych rynków lokalnych pod względem ryzyka inwestycyjnego (rynkowego) oszacowano podstawowe miary ryzyka dla logarytmicznych stóp zwrotu z tzw. portfeli rynkowych, bazując na dziennych wartościach głównych indeksów giełdowych (szero- 
Tabela 1. Wielkość lokalnych rynków funduszy inwestycyjnych i kosztów funduszy (TER) w Polsce i wybranych krajach Europy Zachodniej w 2013 r.

\begin{tabular}{|c|c|c|c|c|c|c|}
\hline \multirow[b]{2}{*}{ Kraj (kod kraju) } & \multicolumn{2}{|c|}{$\begin{array}{l}\text { Lokalny rynek } \\
\text { funduszy }\end{array}$} & \multicolumn{4}{|c|}{ Poziom kosztów (TER) w funduszach (\%) } \\
\hline & $\begin{array}{l}\text { liczba } \\
\text { funduszy }\end{array}$ & $\begin{array}{c}\text { aktywa } \\
\text { netto } \\
\text { (mln EUR) }\end{array}$ & dłużne & akcyjne & mieszane & $\begin{array}{l}\text { gotówkowe } \\
\text { i pieniężne }\end{array}$ \\
\hline Polska (PL) & 679 & 40898 & 1,61 & 4,22 & 4,17 & 1,13 \\
\hline Belgia (BE) & 1616 & 92689 & 0,31 & 1,56 & 1,18 & 0,44 \\
\hline Dania (DK) & 901 & 180853 & 0,64 & 1,43 & 0,64 & 0,42 \\
\hline Francja (FR) & 11504 & 1508431 & 0,60 & 1,77 & 1,64 & 0,16 \\
\hline Hiszpania (ES) & 2335 & 172347 & 1,01 & 1,88 & 0,95 & 0,51 \\
\hline Holandia (NL) & 610 & 68177 & 0,75 & 1,19 & 1,11 & 0,43 \\
\hline Niemcy (DE) & 6057 & 1360873 & 0,70 & 1,44 & 1,38 & 0,57 \\
\hline Norwegia (NO) & 573 & 78168 & 0,50 & 1,87 & 1,26 & 0,35 \\
\hline Szwajcaria $(\mathrm{CH})$ & 918 & 355721 & 0,88 & 1,16 & 1,32 & 0,20 \\
\hline Szwecja (SE) & 560 & 193750 & 0,70 & 1,42 & 1,21 & 0,40 \\
\hline Wielka Brytania (UK) & 2952 & 1070770 & 1,18 & 1,66 & 1,60 & 0,38 \\
\hline Włochy (IT) & 999 & 203639 & 0,99 & 2,13 & 1,49 & 0,41 \\
\hline Średnia arytmetyczna & 2475 & 443860 & 0,82 & 1,81 & 1,50 & 0,45 \\
\hline Mediana & 959 & 187302 & 0,73 & 1,61 & 1,29 & 0,42 \\
\hline $\begin{array}{l}\text { Odchylenie standar- } \\
\text { dowe }\end{array}$ & 3253 & 539253 & 0,34 & 0,81 & 0,89 & 0,24 \\
\hline
\end{tabular}

Źródło: opracowanie własne na podstawie: [Global Fund Investor Experience Report, 2013], EFAMA International Statistical Release (2013:3Q) oraz danych otrzymanych z serwisu Analizy.pl.

kiego rynku lub największych spółek) z rynków akcji poszczególnych krajów od czerwca 2004 r. do grudnia 2013 r. (tabela 2). Dane uszeregowano rosnąco pod względem ryzyka mierzonego odchyleniem standardowym.

Z punktu widzenia każdego inwestora istotna jest ocena realnej wartości bogactwa końcowego osiągniętego w związku z inwestycją w dany fundusz inwestycyjny. Konstrukcja wskaźnika TWR oparta na formule (3) zapewnia otrzymanie jednakowych wyników zarówno w przypadku zastosowania nominalnych, jak i realnych stóp zwrotu do porównania funduszy z danego rynku lokalnego. Zakładając bowiem, że realna stopa zwrotu $\check{r}_{t} \mathrm{w}$ okresie $t$ jest równa ilorazowi nominalnej stopy zwrotu $r_{t}$ oraz wskaźnika inflacji $p_{t} \mathrm{w}$ tym okresie, a zatem:

$$
\left(1+\check{r}_{t}\right)=\frac{\left(1+r_{t}\right)}{\left(1+p_{t}\right)}
$$


to przy równym współczynniku zmian cen towarów i usług $p_{t}$ dla każdej z par porównywanych funduszy w poszczególnych okresach wartość $T W R$ osiąga taki sam poziom niezależnie od wyboru nominalnych czy realnych stóp zwrotu. Uwzględnienie różnic w sile nabywczej poprzez rozróżnienie nominalnych i realnych stóp zwrotu jest konieczne przy ocenie porównawczej wyników z inwestycji $\mathrm{w}$ fundusze $\mathrm{z}$ rynków o odmiennych poziomach wskaźnika inflacji $p_{t} \mathrm{w}$ poszczególnych okresach. Dodatkowo w przypadku oceny inwestycji realizowanych w różnych walutach wymagane jest również określenie zakresu zmian wartości kapitału końcowego wywołanych wahaniami ich kursów.

Tabela 2. Ryzyko rynkowe inwestycji kapitałowych w Polsce i wybranych krajach Europy Zachodniej od czerwca 2004 r. do marca 2014 r.

\begin{tabular}{|l|l|c|c|c|c|c|c|}
\hline \multicolumn{1}{|c|}{ Kraj } & \multicolumn{1}{|c|}{$\begin{array}{c}\text { Indeks } \\
\text { giełdowy }\end{array}$} & Typ indeksu & $\begin{array}{c}\text { Liczba } \\
\text { spółek } \\
\text { w indeksie }\end{array}$ & $\begin{array}{c}\text { Średnia } \\
\text { arytme- } \\
\text { tyczna }\end{array}$ & $\begin{array}{c}\text { Odchy- } \\
\text { lenie } \\
\text { standar- } \\
\text { dowe }\end{array}$ & Skośność & Kurtoza \\
\hline Szwajcaria & SPI & dochodowy & wszystkie & 0,0265 & 1,0979 & $-0,1189$ & 7,8154 \\
\hline Szwajcaria & SMI & cenowy & 20 & 0,0159 & 1,1466 & $-0,0178$ & 8,3951 \\
\hline UK & $\begin{array}{l}\text { FTSE All- } \\
\text {-Share }\end{array}$ & cenowy & wszystkie & 0,0204 & 1,1918 & $-0,2147$ & 7,8586 \\
\hline Belgia & BEL All-Share & dochodowy & wszystkie & 0,0269 & 1,1998 & $-0,2299$ & 8,0344 \\
\hline UK & FTSE 100 & cenowy & 100 & 0,0158 & 1,2272 & $-0,1527$ & 8,6350 \\
\hline Belgia & BEL 20 & cenowy & 20 & 0,0080 & 1,2923 & $-0,1503$ & 6,5579 \\
\hline Polska & WIG & dochodowy & wszystkie & 0,0324 & 1,3195 & $-0,4735$ & 3,5477 \\
\hline Holandia & AEX & cenowy & 25 & 0,0078 & 1,3672 & $-0,2098$ & 9,1635 \\
\hline Holandia & AEX All- & cenowy & wszystkie & 0,0070 & 1,3677 & $-0,4429$ & 13,8455 \\
\hline Niemcy & DAX & dochodowy & 30 & 0,0370 & 1,3934 & 0,0355 & 7,1243 \\
\hline Francja & CAC All-Share & cenowy & wszystkie & 0,0113 & 1,4285 & 0,0259 & 9,2046 \\
\hline Francja & CAC 40 & cenowy & 40 & 0,0069 & 1,4522 & 0,0556 & 6,9437 \\
\hline Szwecja & OMXS & cenowy & 30 & 0,0288 & 1,4686 & 0,0376 & 4,6592 \\
\hline Włochy & FTSE Italia & cenowy & wszystkie & $-0,0123$ & 1,4861 & $-0,0761$ & 5,6117 \\
\hline Hiszpania & IBEX 35 & cenowy & 35 & 0,0096 & 1,5281 & 0,1365 & 7,0144 \\
\hline Polska & WIG 20 & cenowy & 20 & 0,0148 & 1,5599 & $-0,2964$ & 3,0381 \\
\hline Włochy & FTSE MIB & cenowy & 40 & $-0,0148$ & 1,5710 & $-0,0651$ & 5,4597 \\
\hline Norwegia & OSEAX & dochodowy & wszystkie & 0,0452 & 1,5815 & $-0,6373$ & 5,9138 \\
\hline
\end{tabular}

Źródło: opracowanie własne na podstawie danych z serwisów STOOQ, GPW, Euronext, Yahoo Finance. 
W celu wyeksponowania erozyjnego wpływu kosztów funduszy na bogactwo końcowe inwestorów nabywających tytuły uczestnictwa oferowane w Polsce w stosunku do podmiotów inwestujących w fundusze na rynkach finansowych innych krajów europejskich w ramach prowadzonej analizy przyjęto założenie o równych realnych stopach zwrotu brutto osiąganych przez inwestorów na każdym z rynków europejskich. Następnie na bazie formuły (4) oraz zaprezentowanych w tabeli 1 wartościach wskaźników TER dokonano obliczeń współczynników $T W R$ dla inwestycji w poszczególnych krajach w rozbiciu na poszczególne typy funduszy, przyjmując każdorazowo za punkt odniesienia końcową wartość inwestycji w Polsce. W celu uwzględnienia możliwie szerokiego horyzontu inwestycyjnego wartości wskaźnika $T W R$ obliczono dla okresów: 1 rok oraz 5, 10, 15, 20, 25, 30 i 40 lat. Warto w tym miejscu zaznaczyć, że przyjęcie górnej granicy okresu inwestycji na poziomie 40 lat odpowiadać może w przybliżeniu przypadkowi, kiedy inwestor (oszczędzający) przetrzymuje swe środki w funduszu inwestycyjnym przez cały okres aktywności zawodowej do momentu osiągnięcia wieku emerytalnego.

\section{Wyniki}

Uporządkowane malejąco w każdym okresie w ramach poszczególnych typów funduszy wartości wskaźników TWR zaprezentowano w tabelach 2-5. Ranking współczynników $T W R$ odpowiada każdorazowo wyjściowej klasyfikacji poziomów wskaźników kosztów TER (tabela 1), co nie wymaga uzasadnienia, biorąc pod uwagę przyjętą metodykę obliczeń. Na uwagę i głębszą analizę zasługuje jednak skala erozji wartości bogactwa inwestorów alokujących swe środki pieniężne w fundusze działające w Polsce na tle pozostałych krajów europejskich w miarę wydłużania okresu trwania inwestycji.

W przypadku funduszy dłużnych (tabela 3 ) dysproporcje w wartości bogactwa końcowego oszczędzających w funduszach w wybranych krajach mogą dochodzić do ok. 70\% w najdłuższym z rozpatrywanych okresów inwestycyjnych. Przy założeniu jednakowych realnych stóp zwrotu inwestor z Polski może osiągnąć średnio o ponad $42 \%$ niższą wartość kapitału na końcu czterdziestoletniego okresu inwestowania aniżeli inwestorzy na pozostałych analizowanych rynkach zagranicznych.

Znacznie większe rozpiętości wartości bogactwa końcowego w długim horyzoncie czasowym występują w odniesieniu do funduszy akcyjnych (tabela 4). Inwestycja w tego typu fundusze na rynku polskim oznacza dla lokalnych inwestorów średnio ok. 3-krotnie niższą wartość końcową kapitału w porównaniu $\mathrm{z}$ inwestycjami w tożsame fundusze na pozostałych rynkach zagranicznych (dla okresu czterdziestoletniego). 
Tabela 3. Zestawienie wartości wskaźnika $T W R$ dla funduszy dłużnych

\begin{tabular}{|l|c|c|c|c|c|c|c|}
\hline \multirow{2}{*}{ Wskaźnik } & \multicolumn{7}{|c|}{ Długość okresu inwestycji (w latach) } \\
\cline { 2 - 8 } & 1 & 5 & 10 & 15 & 20 & 30 & 40 \\
\hline TWR_BE-PL & 1,0132 & 1,0678 & 1,1403 & 1,2176 & 1,3002 & 1,4826 & 1,6905 \\
\hline TWR_NO-PL & 1,0113 & 1,0577 & 1,1187 & 1,1833 & 1,2515 & 1,4001 & 1,5663 \\
\hline TWR_FR-PL & 1,0103 & 1,0524 & 1,1075 & 1,1656 & 1,2266 & 1,3585 & 1,5046 \\
\hline TWR_DK-PL & 1,0099 & 1,0503 & 1,1031 & 1,1585 & 1,2168 & 1,3422 & 1,4806 \\
\hline TWR_DE-PL & 1,0092 & 1,0471 & 1,0964 & 1,1481 & 1,2022 & 1,3181 & 1,4452 \\
\hline TWR_SE-PL & 1,0092 & 1,0471 & 1,0964 & 1,1481 & 1,2022 & 1,3181 & 1,4452 \\
\hline TWR_NL-PL & 1,0087 & 1,0445 & 1,0909 & 1,1394 & 1,1901 & 1,2983 & 1,4164 \\
\hline TWR_CH-PL & 1,0074 & 1,0377 & 1,0767 & 1,1173 & 1,1593 & 1,2483 & 1,3440 \\
\hline TWR_IT-PL & 1,0063 & 1,0319 & 1,0648 & 1,0988 & 1,1339 & 1,2074 & 1,2857 \\
\hline TWR_ES-PL & 1,0061 & 1,0309 & 1,0627 & 1,0955 & 1,1293 & 1,2001 & 1,2753 \\
\hline TWR_UK-PL & 1,0044 & 1,0220 & 1,0446 & 1,0676 & 1,0911 & 1,1398 & 1,1906 \\
\hline Średnia & 1,0087 & 1,0445 & 1,0911 & 1,1400 & 1,1912 & 1,3012 & 1,4222 \\
\hline $\begin{array}{l}\text { Odchylenie } \\
\text { standardowe }\end{array}$ & 0,0025 & 0,0131 & 0,0274 & 0,0430 & 0,0599 & 0,0980 & 0,1428 \\
\hline
\end{tabular}

Źródło: opracowanie własne.

Tabela 4. Zestawienie wartości wskaźnika $T W R$ dla funduszy akcyjnych

\begin{tabular}{|l|c|c|c|c|c|c|c|}
\hline \multirow{2}{*}{ Wskaźnik } & \multicolumn{7}{|c|}{ Długość okresu inwestycji (w latach) } \\
\cline { 2 - 8 } & 1 & 5 & 10 & 15 & 20 & 30 & 40 \\
\hline TWR_CH-PL & 1,0319 & 1,1703 & 1,3696 & 1,6028 & 1,8757 & 2,5688 & 3,5182 \\
\hline TWR_NL-PL & 1,0316 & 1,1685 & 1,3654 & 1,5955 & 1,8643 & 2,5456 & 3,4757 \\
\hline TWR_SE-PL & 1,0292 & 1,1550 & 1,3340 & 1,5407 & 1,7794 & 2,3737 & 3,1664 \\
\hline TWR_DK-PL & 1,0291 & 1,1544 & 1,3326 & 1,5383 & 1,7758 & 2,3665 & 3,1535 \\
\hline TWR_DE-PL & 1,0290 & 1,1538 & 1,3312 & 1,5360 & 1,7722 & 2,3593 & 3,1408 \\
\hline TWR_BE-PL & 1,0278 & 1,1468 & 1,3151 & 1,5082 & 1,7296 & 2,2746 & 2,9914 \\
\hline TWR_UK-PL & 1,0267 & 1,1410 & 1,3018 & 1,4854 & 1,6948 & 2,2063 & 2,8722 \\
\hline TWR_FR-PL & 1,0256 & 1,1346 & 1,2873 & 1,4606 & 1,6572 & 2,1334 & 2,7465 \\
\hline TWR_NO-PL & 1,0245 & 1,1288 & 1,2743 & 1,4385 & 1,6238 & 2,0692 & 2,6368 \\
\hline TWR_ES-PL & 1,0244 & 1,1283 & 1,2730 & 1,4363 & 1,6205 & 2,0629 & 2,6261 \\
\hline TWR_IT-PL & 1,0218 & 1,1140 & 1,2409 & 1,3824 & 1,5399 & 1,9109 & 2,3713 \\
\hline Średnia & 1,0274 & 1,1450 & 1,3114 & 1,5022 & 1,7212 & 2,2610 & 2,9726 \\
\hline $\begin{array}{l}\text { Odchylenie } \\
\text { standardowe }\end{array}$ & 0,0032 & 0,0176 & 0,0402 & 0,0690 & 0,1052 & 0,2067 & 0,3613 \\
\hline
\end{tabular}

Źródło: opracowanie własne. 
Tabela 5. Zestawienie wartości wskaźnika TWR dla funduszy mieszanych

\begin{tabular}{|l|c|c|c|c|c|c|c|}
\hline \multirow{2}{*}{ Wskaźnik } & \multicolumn{7}{|c|}{ Długość okresu inwestycji (w latach) } \\
\cline { 2 - 8 } & 1 & 5 & 10 & 15 & 20 & 30 & 40 \\
\hline TWR_DK-PL & 1,0368 & 1,1983 & 1,4358 & 1,7205 & 2,0616 & 2,9601 & 4,2501 \\
\hline TWR_ES-PL & 1,0336 & 1,1797 & 1,3916 & 1,6417 & 1,9367 & 2,6952 & 3,7508 \\
\hline TWR_NL-PL & 1,0319 & 1,1702 & 1,3693 & 1,6024 & 1,8751 & 2,5676 & 3,5159 \\
\hline TWR_BE-PL & 1,0312 & 1,1660 & 1,3597 & 1,5854 & 1,8487 & 2,5136 & 3,4177 \\
\hline TWR_SE-PL & 1,0309 & 1,1643 & 1,3555 & 1,5782 & 1,8375 & 2,4908 & 3,3764 \\
\hline TWR_NO-PL & 1,0304 & 1,1613 & 1,3487 & 1,5663 & 1,8190 & 2,4533 & 3,3088 \\
\hline TWR_CH-PL & 1,0297 & 1,1578 & 1,3405 & 1,5521 & 1,7970 & 2,4090 & 3,2293 \\
\hline TWR_DE-PL & 1,0291 & 1,1543 & 1,3324 & 1,5380 & 1,7753 & 2,3654 & 3,1517 \\
\hline TWR_IT-PL & 1,0280 & 1,1479 & 1,3176 & 1,5125 & 1,7361 & 2,2875 & 3,0141 \\
\hline TWR_UK-PL & 1,0268 & 1,1415 & 1,3030 & 1,4873 & 1,6977 & 2,2121 & 2,8823 \\
\hline TWR_FR-PL & 1,0264 & 1,1392 & 1,2977 & 1,4783 & 1,6840 & 2,1853 & 2,8358 \\
\hline Średnia & 1,0304 & 1,1619 & 1,3502 & 1,5693 & 1,8244 & 2,4673 & 3,3394 \\
\hline $\begin{array}{l}\text { Odchylenie } \\
\text { standardowe }\end{array}$ & 0,0030 & 0,0171 & 0,0400 & 0,0700 & 0,1091 & 0,2233 & 0,4067 \\
\hline
\end{tabular}

Źródło: opracowanie własne.

Tabela 6. Zestawienie wartości wskaźnika TWR dla funduszy gotówkowych i pieniężnych

\begin{tabular}{|l|c|c|c|c|c|c|c|}
\hline \multirow{2}{*}{ Wskaźnik } & \multicolumn{7}{|c|}{ Długość okresu inwestycji (w latach) } \\
\cline { 2 - 8 } & 1 & 5 & 10 & 15 & 20 & 30 & 40 \\
\hline TWR_FR-PL & 1,0098 & 1,0500 & 1,1026 & 1,1577 & 1,2156 & 1,3403 & 1,4778 \\
\hline TWR_CH-PL & 1,0094 & 1,0479 & 1,0981 & 1,1508 & 1,2059 & 1,3243 & 1,4543 \\
\hline TWR_NO-PL & 1,0079 & 1,0401 & 1,0818 & 1,1251 & 1,1702 & 1,2659 & 1,3693 \\
\hline TWR_UK-PL & 1,0076 & 1,0385 & 1,0785 & 1,1200 & 1,1632 & 1,2545 & 1,3529 \\
\hline TWR_SE-PL & 1,0074 & 1,0375 & 1,0763 & 1,1167 & 1,1585 & 1,2469 & 1,3421 \\
\hline TWR_IT-PL & 1,0073 & 1,0369 & 1,0753 & 1,1150 & 1,1562 & 1,2432 & 1,3367 \\
\hline TWR_DK-PL & 1,0072 & 1,0364 & 1,0742 & 1,1133 & 1,1539 & 1,2394 & 1,3314 \\
\hline TWR_NL-PL & 1,0071 & 1,0359 & 1,0731 & 1,1116 & 1,1515 & 1,2357 & 1,3260 \\
\hline TWR_BE-PL & 1,0070 & 1,0354 & 1,0720 & 1,1100 & 1,1492 & 1,2320 & 1,3207 \\
\hline TWR_ES-PL & 1,0063 & 1,0318 & 1,0645 & 1,0983 & 1,1332 & 1,2063 & 1,2841 \\
\hline TWR_DE-PL & 1,0057 & 1,0286 & 1,0581 & 1,0884 & 1,1196 & 1,1846 & 1,2535 \\
\hline Średnia & 1,0075 & 1,0381 & 1,0777 & 1,1188 & 1,1615 & 1,2521 & 1,3499 \\
\hline $\begin{array}{l}\text { Odchylenie } \\
\text { standardowe }\end{array}$ & 0,0012 & 0,0062 & 0,0130 & 0,0202 & 0,0281 & 0,0456 & 0,0658 \\
\hline
\end{tabular}

Źródło: opracowanie własne. 
Największy zakres erozji wartości bogactwa końcowego można zaobserwować w odniesieniu do funduszy mieszanych (tabela 5). Różnice w wysokości kosztów obciążających fundusze skutkują w długim okresie (40 lat) średnio ponadtrzykrotnie większym ubytkiem końcowej wartości bogactwa w Polsce aniżeli w pozostałych krajach. Największe dysproporcje wartości inwestycji w fundusze działające w Polsce odnotować można w porównaniu do inwestycji w fundusze oferowane w Danii, Hiszpanii i Holandii, najmniejsze natomiast - do funduszy ze Włoch, Wielkiej Brytanii i Francji.

Inwestowanie w fundusze gotówkowe i pieniężne cechuje się najniższym spośród analizowanej grupy funduszy stopniem erozji wartości bogactwa inwestorów wywołanym wielkością obciążeń kosztowych, odzwierciedlonych w poziomie wskaźnika TER (tabela 6). Mimo to w długim okresie (40 lat) inwestycja w fundusz działający w Polsce może przynieść od 25\% do ok. 50\% mniejszą wartość bogactwa końcowego niż inwestycja w porównywalne fundusze działające za granicą.

\section{Zakończenie}

Z przedstawionej analizy wynika, że wywołana wysokością obciążeń kosztowych skala erozji bogactwa końcowego związanego z inwestowaniem w fundusze w przypadku Polski znacznie przewyższa - ceteris paribus - porównywalne inwestycje realizowane w objętych badaniami krajach europejskich. Dysproporcja w wartości końcowej kapitału jest pochodną wysokości naliczanych opłat manipulacyjnych oraz kosztów operacyjnych i pogłębia się w miarę wydłużania horyzontu inwestycyjnego. Przykładowo (dla czterdziestoletniego okresu inwestycji) wywołana wyłącznie dysproporcją w kosztach wysokość końcowych wyników z inwestycji osiąganych przez inwestorów z Polski różni się średnio od wyników europejskich o 35\% w przypadku funduszy gotówkowych i pieniężnych, o $42 \%$ - w przypadku funduszy dłużnych, o 197\% - w przypadku funduszy akcyjnych oraz o $234 \%$ - w przypadku funduszy mieszanych.

Jedną z przyczyn takiego stanu jest niedojrzałość polskiego rynku funduszy inwestycyjnych na tle analizowanych krajów europejskich. Wprawdzie pod względem liczby funduszy rynek polski jest większy aniżeli rynki w Szwecji, Norwegii czy Holandii (tabela 1), a mierzone odchyleniem standardowym ryzyko rynkowe inwestycji na lokalnym rynku akcji nie odbiega od poziomów notowanych na rynkach zagranicznych (tabela 2), niemniej w dalszym ciągu odstaje on od pozostałych rynków, biorąc pod uwagę liczbę zgromadzonych aktywów netto (tabela 1). Paradoksalnie za relatywnie niską wartość aktywów netto funduszy odpowiada $\mathrm{w}$ istotnej części właśnie wysoki poziom obciążeń kosztowych, 
który z jednej strony zniechęca inwestorów do lokowania środków pieniężnych w funduszach, z drugiej zaś strony „pochłania” niewspółmiernie dużą część wartości powierzanych im w zarządzanie aktywów.

Znaczna dysproporcja w wysokości prowizji i opłat inkasowanych przez fundusze działające w Polsce i w analizowanych krajach europejskich świadczy także o niskiej świadomości ekonomicznej rodzimych inwestorów. Rezygnując z aktywnych poszukiwań alternatywnych możliwości inwestycyjnych, wybierają oni tę formę inwestycji i akceptują równocześnie proponowane przez fundusze warunki uczestnictwa, w tym poziom obciążeń kosztowych.

Prawnoorganizacyjne ramy systemu alokacji oszczędności społeczeństwa kreowane są przez instytucje publiczne odpowiedzialne za nadzór i funkcjonowanie tego segmentu rynku finansowego. Zgodnie z zapisami opracowanej przez Ministerstwo Finansów w 2004 r. strategii rozwoju rynku kapitałowego „misją państwa na rynku kapitałowym w Polsce jest stworzenie warunków dla rozwoju taniego, efektywnego i bezpiecznego mechanizmu konwersji oszczędności społeczeństwa w krajowe inwestycje i finansowanie krajowych przedsiębiorstw" [Strategia rozwoju rynku kapitałowego... 2004, s. 3]. Z przeprowadzonej analizy wynika, że określone w misji cele dotychczas nie zostały osiągnięte, przynajmniej w zakresie dotyczącym kosztów funkcjonowania funduszy inwestycyjnych. Jest to zastanawiające, gdyż w praktyce dostępne jest wiele narzędzi, umożliwiających ochronę wartości oszczędności inwestorów przed erozją wywołaną obciążeniami kosztowym generowanymi przez fundusze (np. limity maksymalnych procentowych stawek wynagrodzeń, hurdle rate, high-water mark, clawback). Priorytetem działań systemowych powinno być przede wszystkim stworzenie mechanizmów uzależniających wypłatę wynagrodzeń funduszy od pozytywnych wyników inwestycyjnych osiąganych przez inwestorów (oszczędzających). Brak wystarczającego zaangażowania instytucji publicznych w tym obszarze przyczynia się równocześnie do wydłużania procesu konwergencji polskiego systemu alokacji oszczędności z systemami rozwiniętych krajów europejskich.

\section{Literatura}

Bello Z.Y., Frank L.A.C. [2010], A Re-examination of the Impact of Expenses on the Performance of Actively Managed Equity Mutual Funds, „European Journal of Finance and Banking Research", vol. 3, nr 3.

Carhart M.M. [1997], On the Persistence in Mutual Fund Performance, „Journal of Finance", vol. 52.

Dawidowicz D. [2011], Fundusze inwestycyjne: rodzaje, metody oceny, analiza, z uwzględnieniem światowego kryzysu, CeDeWu.pl, Warszawa. 
Ellis C.D. [2012], Investment Management Fees Are (Much) Higher Than You Think, „Financial Analysts Journal”, vol. 68, nr 3 (May/June), http://dx.doi.org/10.2469/faj. v68.n3.2.

Global Fund Investor Experience Report [2013], Morningstar Fund Research, May, http:// corporate.morningstar.com/US/documents/MethodologyDocuments/FactSheets/Global-Fund-Investor-Experience-Report-2013.pdf (dostęp: 11.12.2013).

Grinblatt M., Titman S. [1989], Mutual Fnnd Performance: An Analysis of Quarterly Portfolio Holdings, ,Journal of Business”, vol. 62, nr 3, http://dx.doi.org/10.1086/296468.

Hooks J.A. [1996], The Effect of Loads and Expenses on Open-End Mutual Fund Returns, „Journal of Business Research”, vol. 36, http://dx.doi.org/10.1016/01482963(95)00169-7.

Houge T., Wellman J. [2007], The Use and Abuse of Mutual Fund Expenses, „Journal of Business Ethics", vol. 70, http://dx.doi.org/10.1007/s10551-006-9077-6.

Khorana A., Servaes S., Tufano P. [2008], Mutual Fund Fees Around the World, „The Review of Financial Studies", vol. 22, nr 3.

Krawiec W. [2003], Koszty uczestnictwa w funduszach inwestycyjnych, Prace Naukowe Akademii Ekonomicznej we Wrocławiu, nr 982, Wrocław.

Księżak A. [2013a], Czy polskie fundusze moga być tańsze?, http://www.analizy.pl/ fundusze/wiadomosci/14622/czy-polskie-fundusze-moga-byc-tansze.html (dostęp: 11.12.2013).

Księżak A. [2013b], Fundusze gotówkowe i pieniężne coraz droższe, http://www.analizy. $\mathrm{pl} /$ fundusze/wiadomosci/14546/fundusze-gotowkowe-i-pieniezne-coraz-drozsze.html (dostęp: 11.12.2013).

Oleksy P. [2013], Wysokość opłat za zarzadzanie a efektywność polskich funduszy nieruchomości, „Annales UMCS Sectio H - Ekonomia”, nr 47.

Otten R., Bams D. [2002], European Mutual Fund Performance, „European Financial Management", vol. 8, http://dx.doi.org/10.1111/1468-036x.00177.

Palica Z. [2007], Wptyw opłat manipulacyjnych na wyniki funduszy inwestycyjnych w latach 1998-2005, Zeszyty Naukowe Uniwersytetu Szczecińskiego, nr 455, Szczecin.

Perez K. [2012], Efektywność funduszy inwestycyjnych - podejście techniczne i fundamentalne, Difin, Warszawa.

Strategia rozwoju rynku kapitałowego „Agenda Warsaw City 2010” [2004], Ministerstwo Finansów, Warszawa.

Sharpe W. [2013], The Arithmetic of Investment Expenses, „Financial Analysts Journal”, vol. $59, \mathrm{nr} 2$.

Wermers R. [2000], Mutual Fund Performance: An Empirical Decomposition into Stock-Picking Talent, Style, Transactions, Costs, and Expenses, „Journal of Finance”, vol. 55, http://dx.doi.org/10.1111/0022-1082.00263.

Worldwide Investment Fund Assets and Flows, Trends in the Third Quarter [2013], European Fund and Asset Management Association (EFAMA), International Statistical Release, http://www.efama.org/Publications/Statistics/International/Quarterly\%20\%20International/ 140107_International\%20Statistical\%20Release $\% 20$ 2013\%20Q3.pdf (dostęp: 4.02.2014).

Zamojska A. [2012], Efektywność funduszy inwestycyjnych w Polsce. Studium teoretyczno-empiryczne, C.H. Beck, Warszawa. 


\section{The Erosive Effect of Mutual Fund Expenses on the Terminal Wealth Value of Investors in Poland and Other European Countries}

One factor that has a critical impact on mutual fund investors' terminal wealth is the fees which investors incur directly or indirectly in connection with establishing and maintaining their investment. Applying the Sharpe's Terminal Wealth Ratio Analysis, this study shows that cost burdens imposed by mutual funds operating in Poland greatly exceed the cost burdens of comparable investments made in more developed European countries, magnifying the erosive effect on investors' terminal wealth value, especially as the investment horizon is extended. For example, over a forty-year investment period the reduction in investment performance (investors' terminal wealth value) attributed only to the disparity of mutual fund fees in Poland compared with the other European countries, on average, are as follows: about $35 \%$ in money market funds, $42 \%$ for fixedincome funds, $197 \%$ in the case of equity funds, and $234 \%$ in the case of allocation funds. This fact demonstrates both the immaturity of the Polish mutual fund market and a lack of economic knowledge and experience among domiciled investors. This, coupled with the absence of sufficient involvement of public institutions to create a cheap, efficient and safe allocation mechanism for investors' savings, contributes to a much deeper erosion of their wealth than in developed countries.

Keywords: mutual funds, fund fees and expenses, terminal wealth value, wealth erosion. 